STUDIA EDUKACYJNE NR 31/2014

\title{
KOMPETENCJE I OCZEKIWANIA NAUCZYCIELA DO PRACY Z DZIECKIEM ZE SPECJALNYMI POTRZEBAMI EDUKACYJNYMI. KOMUNIKAT Z BADAŃ
}

\begin{abstract}
Buchnat Marzena, Kompetencje i oczekiwania nauczyciela do pracy z dzieckiem ze specjalnymi potrzebami edukacyjnymi. Komunikat $z$ badań [Competences and Expectations of Teacher's Working with Children with Special Educational Needs. Research Interim Report]. Studia Edukacyjne nr 31, 2014, Poznań 2014, pp. 177-194. Adam Mickiewicz University Press. ISBN 978-83-232-2781-6. ISSN 1233-6688

Recent legal changes in the educational system have ensured children with mild intellectual disabilities the opportunity to study in public schools; as a result more and more children avail themselves of it. In connection with this trend we can ask: "How are the teachers of these schools ready to accept them?" After all, during the implementation of the reform in the educational system it is teachers that are the most important element determining the effectiveness of the proposed changes. They should guarantee the appropriate quality of education for children with disabilities. However, the studies conducted raise serious reservations, both as to their preparation and willingness to prepare for effective work with students with mild intellectual disabilities.
\end{abstract}

Key words: teacher, competence, public school, a student with a mild intellectual disability

Trwająca obecnie cały czas reforma sytemu edukacji specjalnej skierowana jest na włączenie osób z niepełnosprawnością do ogólnodostępnego sytemu kształcenia. Zmiany te zostały zapoczątkowane już dekretem z 23 marca 1956 r. o obowiązku szkolnym ${ }^{1}$, zapisami w Konstytucji², czy Ustawą o systemie oświaty ${ }^{3}$, mającą na celu zagwarantowanie prawa do nauki dzieciom niepełnosprawnym $w$ Polsce.

${ }^{1}$ DzU nr 9, poz. 52 z późn. zm.

2 Art. 32, 70.

${ }^{3}$ Z 7 września 1991 r. DzU z 2004 r. nr 256, poz. 2572, art. 1 ust. 4-6. 
Reforma sytemu edukacji jest ściśle związana ze zmianą postaw społecznych wobec osób niepełnosprawnych. Stanowi odzwierciedlenie ewaluacji miejsca osoby $\mathrm{z}$ niepełnosprawnością $\mathrm{w}$ społeczeństwie, przejścia od segregacji, integracji, po normalizację. Zmiana paradygmatu w myśleniu o niepełnosprawności wynika, jak uważa Cz. Kosakowski, z odbiologizowania zjawiska odchylenia od normy, zwracając przy tym szczególną uwagę na kontekst społeczny niepełnoprawności, przez co został przesunięty sposób postrzegania osób niepełnosprawnych z perspektywy ograniczeń na perspektywę możliwości. Takie przeobrażenia w sposobie myślenia o niepełnosprawności stanowią podstawę do normalizacji życia osób z niepełnosprawnością, stąd poczyniono dalsze nowelizacje prawne służące urzeczywistnieniu tego nurtu społecznych zmian.

Następnym znaczącym krokiem w poszerzeniu oferty edukacyjnej dla uczniów z niepełnosprawnością było opracowanie wspólnej podstawy programowej kształcenia ogólnego, zarówno dla uczniów pełnosprawnych jak i niepełnosprawnych (słabo słyszących i niesłyszących, słabo widzących i niewidomych, niepełnosprawnych ruchowo, z upośledzeniem umysłowym w stopniu lekkim). Wspólna podstawa programowa stworzyła możliwość nauczania dzieci o specjalnych potrzebach edukacyjnych w warunkach klasy integracyjnej czy ogólnodostępnej, umożliwiła też dzieciom niepełnosprawnym swobodną zmianę szkoły podczas edukacji na danym etapie lub po jego zakończeniu ${ }^{5}$.

Dzięki stworzeniu jednolitej podstawy programowej możliwe stało się przyjęcie do szkół ogólnodostępnych dzieci z orzeczeniem o potrzebie kształcenia specjalnego, na co pozwala Rozporządzenie z 17 listopada 2010 r. w sprawie zasad udzielania i organizacji pomocy psychologiczno-pedagogicznej w publicznych przedszkolach, szkołach i placówkach ${ }^{6}$ i Rozporządzenie z 17 listopada 2010 r. w sprawie warunków organizowania kształcenia, wychowania i opieki dla dzieci i młodzieży niepełnosprawnych oraz niedostosowanych społecznie w przedszkolach, szkołach i oddziałach ogólnodostępnych lub integracyjnych (DzU z 2011 r., nr 228, poz. 1490). Rozporządzenie to precyzuje stosowaną terminologię specjalnych potrzeb edukacyjnych (SPE), odnosząc je między innymi do ucznia z niepełnosprawnością. Określa, jakie są ścieżki wsparcia rozwoju dzieci ze SPE w systemach kształcenia ogólnodostępnego, integracyjnego, jak i specjalnego (Karta Indywidu-

${ }^{4}$ Cz. Kosakowski, Dziecko niepetnosprawne w szkole masowej - możliwości i ograniczenia, [w:] Dziecko o specjalnych potrzebach edukacyjnych, red. Cz. Kosakowski, M. Zaorska, Torun 2001.

${ }^{5}$ Rozporządzenie MENiS z 26 lutego 2002 r. w sprawie podstawy programowej wychowania przedszkolnego oraz kształcenia ogólnego w poszczególnych typach szkół DzU nr 51 poz. 458, z późn. zm.: DzU nr 210 z 2003 r. poz. 2041; DzU nr 19 z 2005 r. poz. 165.

${ }^{6}$ DzU z 2011 r. nr 228, poz. 1487. 
alnych Potrzeb Ucznia, Plan Działań Wspierających (PDW), Indywidualny Program Edukacyjno Terapeutycznych (IPET)). Dzięki tym rozporządzeniom można stwierdzić, iż obecnie $w$ Polsce mamy do czynienia $\mathrm{z}$ trzema formami kształcenia uczniów z niepełnosprawnością (należących do grupy dzieci ze specjalnymi potrzebami edukacyjnymi): segregacyjną (szkoły specjalne), integracyjną (szkoły/klasy integracyjne), inkluzyjną (szkoły ogólnodostępne).

Implikacją tego stanu jest rosnąca liczba dzieci z niepełnosprawnością realizujących obowiązek szkolny w szkołach ogólnodostępnych, na co wskazują dane $\mathrm{z}$ raportu GUS Oświata $i$ wychowanie w roku szkolnym 2006/2007, 2009/2010, 2010/2011, przedstawione w tabeli 1 .

Tabela 1

Niepełnosprawni uczniowie szkół podstawowych ogólnodostępnych i specjalnych według rodzaju niepełnosprawności

\begin{tabular}{|c|c|c|c|c|c|c|}
\hline Rok szkolny & \multicolumn{2}{|c|}{$2006 / 2007$} & \multicolumn{2}{|c|}{$2009 / 2010$} & \multicolumn{2}{|c|}{$2010 / 211$} \\
\hline rodzaj szkolnictwa & $\begin{array}{l}\text { ogólno- } \\
\text { dostęp- } \\
\text { ne }\end{array}$ & $\begin{array}{l}\text { specjal- } \\
\text { ne }\end{array}$ & $\begin{array}{l}\text { ogólno- } \\
\text { dostęp- } \\
\text { ne }\end{array}$ & $\begin{array}{l}\text { specjal- } \\
\text { ne }\end{array}$ & $\begin{array}{l}\text { ogólno- } \\
\text { dostęp- } \\
\text { ne }\end{array}$ & $\begin{array}{l}\text { specjal- } \\
\text { ne }\end{array}$ \\
\hline uczniowie & 43740 & 31220 & 38090 & 24807 & 36291 & 24481 \\
\hline \multicolumn{7}{|c|}{ Z TEGO WEDŁUG RODZAJU NIEPEŁNOSPRAWNOŚCI } \\
\hline niesłyszący & 186 & 920 & 187 & 525 & 168 & 499 \\
\hline słabosłyszący & 2796 & 284 & 2887 & 285 & 2947 & 306 \\
\hline niewidomi & 41 & 178 & 59 & 104 & 42 & 101 \\
\hline słabowidzący & 1858 & 232 & 1981 & 206 & 2097 & 198 \\
\hline $\begin{array}{l}\text { z niepełnosprawnością } \\
\text { ruchową }\end{array}$ & 4017 & 21 & 3555 & 66 & 3678 & 58 \\
\hline $\begin{array}{l}\text { z lekką niepełnospraw- } \\
\text { nością intelektualną }\end{array}$ & 17202 & 14493 & 12218 & 8971 & 11722 & 8407 \\
\hline $\begin{array}{l}\text { z umiarkowaną lub } \\
\text { znaczną niepełnospraw- } \\
\text { nością intelektualną }\end{array}$ & 2996 & 7222 & 3267 & 7641 & 3070 & 7770 \\
\hline $\mathrm{z}$ autyzmem & 262 & 127 & 1655 & 222 & 2242 & 283 \\
\hline $\begin{array}{l}\text { z niepełnosprawnościami } \\
\text { sprzężonymi }\end{array}$ & 3240 & 3408 & 3694 & 5182 & 3397 & 5336 \\
\hline $\begin{array}{l}\text { niedostosowani społecz- } \\
\text { nie }\end{array}$ & 165 & 433 & 606 & 478 & 233 & 408 \\
\hline $\begin{array}{l}\text { zagrożeni niedostosowa- } \\
\text { niem społecznym }\end{array}$ & 522 & 250 & 875 & 370 & 763 & 503 \\
\hline zagrożeni uzależnieniem & 59 & 12 & 21 & 11 & 1 & 17 \\
\hline $\begin{array}{l}\text { z zaburzeniami zacho- } \\
\text { wania }\end{array}$ & 4683 & 376 & 4487 & 529 & 4115 & 460 \\
\hline $\begin{array}{l}\text { z zaburzeniami } \\
\text { psychicznymi }\end{array}$ & 171 & 104 & 670 & 106 & 538 & 34 \\
\hline przewlekle chorzy & 4547 & 516 & 1928 & 111 & 1279 & 101 \\
\hline
\end{tabular}

Źródło: Oświata $i$ wychowanie w roku szkolnym 2006/2007, 2009/2010, 2010/2011, GUS (www.stat.gov.pl, [dostęp: 12.03.2013]). 
Analizując powyższe dane, można dostrzec zmianę głównie w realizacji obowiązku szkolnego przez dzieci z lżejszym stopniem niepełnosprawności, np. dzieci z lekką niepełnosprawnością intelektualną, słabowidzących czy słabosłyszących; dzieci te przechodzą ze szkolnictwa specjalnego do szkolnictwa ogólnodostępnego ${ }^{7}$. W związku z tendencją zgodną z założeniami reformy systemu kształcenia osób z niepełnosprawnością, można zadać pytanie: na ile są przygotowani nauczyciele szkół ogólnodostępnych do przyjęcia dzieci z niepełnosprawnością?

Przeprowadzone liczne badania odnośnie sytuacji uczniów z niepełnosprawnością w szkolnictwie ogólnodostępnym nie są one niestety optymistyczne ${ }^{8}$. Większość tych badań wskazuje na niższą pozycję ucznia z niepełnosprawnością w klasie, na mniejszą motywację do nauki, czy małe szanse osiągnięcia sukcesu. Implikuje to stwierdzenie, że szkoły nie są jeszcze przygotowane na przyjęcie uczniów z niepełnosprawnością, ponieważ nie potrafią im zapewnić optymalnych warunków dla ich wszechstronnego rozwoju.

Na taki obraz rzeczywistości szkolnej ogromny wpływ ma postawa nauczyciela, jego kompetencje do pracy, a obecnie do pracy z dzieckiem ze specjalnymi potrzebami edukacyjnymi. To oni stanowią jedno ze źródeł powodzenia założeń tej reformy.

Jak wskazuje A. Zamkowska9 ${ }^{9}$, wysokie wymagania postawione szkołom ogólnodostępnym, odnoszące się do zaspokojenia specjalnych potrzeb edukacyjnych uczniom z niepełnosprawnością, opierają się głównie na pracy nauczyciela. Na etapie wdrażania reformy systemu edukacji

najważniejszym elementem warunkującym skuteczność projektowanych zmian są nauczyciele. To ich zaangażowanie i przekonanie przesądza o końcowym sukcesie,

${ }_{7}$ Cz. Kosakowski, Dziecko niepetnosprawne w kształceniu integracyjnym, [w:] Nauczanie i wychowanie osób lekko upośledzonych umystowo, red. Cz. Kosakowski, Toruń 2000.

${ }^{8}$ M.in.: M. Chodkowska, Problemy pedagogicznego wsparcia uczniów z niepetnosprawnościa intelektualna w zakresie społecznego funkcjonowania w klasie szkolnej, [w:] Wsparcie społeczne w rehabilitacji i resocjalizacji, red. Z. Palak, Z. Bartkowicz, Lublin 2004; K. Ćwirynkało, Pozycja socjometryczna uczniów niepetnosprawnych a postawa nauczycieli wobec integracji, [w:] Integracja osób niepetnosprawnych w edukacji i interakcjach spotecznych, red. Z. Kazanowski, D. Osik-Chudowolska, Lublin 2003; D. Osik-Chudowolska, Ustosunkowania emocjonalne uczniów petnosprawnych do niepetnosprawnych rówieśników w szkole $z$ oddziatami integracyjnymi, [w:] Dyskursy pedagogiki specjalnej. Rehabilitacja, opieka i edukacja specjalna w perspektywie zmian, red. U. Bartnikowska, Cz. Kosakowski, A. Krause, Olsztyn 2008; K. Parys, Problemy integracji szkolnej w badaniach empirycznych - przegląd materiatów pokonferencyjnych, [w:] Problemy edukacji integracyjnej dzieci i młodzieży z niepetnosprawnościa intelektualna, red. Z. Janiszewska-Nieścioruk, Kraków 2009; A. Zamkowska Wsparcie edukacyjne uczniów z upośledzeniem umystowym w stopniu lekkim w różnych formach kształcenia na I etapie edukacji, Radom 2009.

${ }_{9}^{9}$ A. Zamkowska, Wsparcie edukacyjne uczniów z upośledzeniem umystowym w stopniu lekkim, s. 59. 
a wykazywany opór wydatnie utrudnia, czasem wręcz uniemożliwia efektywne wdrażanie reformy ${ }^{10}$.

Skoro oczywista wydaje się znacząca rola nauczycieli $\mathrm{w}$ procesie dokonywanych zmian, to dlaczego ich przygotowanie do pracy z dziećmi z niepełnosprawnością budzi zastrzeżenia?

Badania przeprowadzone między innymi przez: D. Al-Kamisy, U. Bartnikowską i M. Wójcik, E. Garlej-Drzewiecką, Z. Gajdzicę i D. Jankowskąa11 wskazują na niski stopień przygotowania nauczycieli do pracy z dziećmi ze specjalnymi potrzebami edukacyjnymi. Niski poziom tego przygotowania lub wręcz jego brak potwierdzają badania analizujące błędy popełniane przez nauczycieli w pracy z uczniem z niepełnosprawnością. Badania prze-

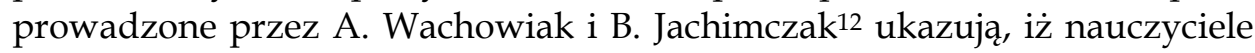
pracujący z uczniami z niepełnosprawnością mają problemy z adekwatnym stawianiem im wymagań, które nie przekraczałyby ich możliwości. Wykazują oni niskie kompetencje $w$ rozpoznawaniu potrzeb dzieci ze SPE oraz nie potrafią dostosować programu do ich możliwości. Badani nauczyciele często oceniali dzieci przez pryzmat ich zaburzeń, charakteryzując się niewłaściwymi postawami wychowawczymi. Wymienione błędy potwierdzają, oczywiście, brak gotowości do pracy z uczniem ze SPE, ale pokazują również, że ich przyczyna może być związana z brakiem wiedzy i umiejętności, jak również brakiem gotowości do pracy z dzieckiem z niepełnosprawno-

10 Z. Gajdzica, Opinie nauczycieli szkót ogólnodostępnych na temat edukacji włączajacej uczniów z lekkim upośledzeniem umysłowym w kontekście toczacej się reformy kształcenia specjalnego, [w:] Uczeń z niepetnosprawnością w szkole ogólnodostępnej, red. Z. Gajdzica, Sosnowiec 2011, s. 60.

11 D. Al-Kamisy, Gotowość nauczycieli edukacji przedszkolnej do pracy z dziećmi o specjalnych potrzebach edukacyjnych, [w:] Integracja społeczna osób niepetnosprawnych, red. G. Dryżałowska, H. Żuraw, Warszawa 2004; U. Bartnikowska, M. Wójcik, Zaniedbania w aspekcie triady: szkołarodzice-dziecko w kształceniu integracyjnym i masowym dzieci z wada stuchu, [w:] Wątki zaniedbane, zaniechane, nieobecne $w$ procesie edukacji $i$ wsparcia społecznego osób niepetnosprawnych, red. Z. Gajdzica, D. Osik-Chudowolska, Lublin 2004; E. Garlej-Drzewiecka, Pedeutologiczny kontekst myślenia o nauczycielu wiodacym i wspierającym, [w:] Dyskursy pedagogiki specjalnej. Wspótczesne problemy pedagogiki specjalnej, red. Cz. Kosakowski, A. Krause, Olsztyn 2004; Z. Gajdzica, Nauczyciel edukacji wczesnoszkolnej w zreformowanej szkole powszechnej jako organizator procesu ksztatcenia dziecka upośledzonego umysłowo w stopniu lekkim, [w:] Pedagogika specjalna w reformowanym ustroju edukacyjnym, red. Z. Palak, Lublin 2001; tenże, Opinie nauczycieli szkół ogólnodostępnych; D. Jankowska, Uczeń z niepetnosprawnościa intelektualna w stopniu lekkim w szkole ogólnodostępnej - problem czy wyzwanie, [w:] Uczeń z niepetnosprawnościa.

12 A. Wachowiak, Błędy nauczycieli szkót masowych w postępowaniu z dziećmi niepetnosprawnymi, [w:] Uczeń niepetnoprawny w szkole masowej, red. A. Hulek, B. Grochmal-Bach, Kraków 1992; B. Jachimczak, Gotowość nauczycieli szkót ogólnodostępnych do pracy z uczniem o specjalnych potrzebach edukacyjnych, [w:] Miejsce Innego we wspótczesnych naukach o wychowaniu - wyzwania praktyki, red. I. Chrzanowska, B. Jachimczak, Łódź 2008. 
ścią. Na brak tej gotowości zwraca uwagę I. Chrzanowska13, która za K. Błeszyńską przytacza stwierdzenie, iż nauczyciele zarówno w Polsce $(85 \%)$, jak i na świecie $(80 \%)$ gdyby mogli samodzielnie podjąć decyzję, nie przyjęliby do swojej klasy ucznia z niepełnosprawnością.

Przytoczone wyniki badań wskazują, że realizacja standardów pracy $\mathrm{z}$ uczniem ze SPE określonych $\mathrm{w}$ rozporządzeniach ministerialnych stoi pod dużym znakiem zapytania. Reforma systemu edukacji specjalnej staje się jednak niezaprzeczalnym faktem. Włączenie $w$ nurt ogólnodostępnego kształcenia uczniów z niepełnosprawnością jest nową rzeczywistością polskich szkól, która wymusza rozszerzenie kompetencji zawodowych nauczycieli. Warto jednak zadbać, aby nauczyciele przygotowali się do pracy $\mathrm{z}$ uczniem o SPE, a nie eksperymentując poszerzali swoje kompetencje, nie zawsze w pożądanym kierunku. Istotne zatem wydaje się określenie, jakie oczekiwania, potrzeby mają nauczyciele szkół ogólnodostępnych związane $\mathrm{z}$ podjęciem pracy lub pracą z uczniem $\mathrm{z}$ niepełnosprawnością.

Biorąc pod uwagę, że każdy rodzaj niepełnosprawności wiąże się ze specyfiką potrzeb edukacyjnych, do badań wybrano jeden rodzaj niepełnosprawności - niepełnosprawność intelektualną. Wybór ten był podyktowany faktem, iż najnowsze rozporządzenie z 17 listopada 2010 r., właśnie w stosunku do tej grupy uczniów w znaczący sposób zmieniło dostęp do kształcenia ogólnodostępnego. Celem przeprowadzonych badań było wskazanie, czy nauczyciele $\mathrm{w}$ związku ze zmianami $\mathrm{w}$ szkolnictwie otrzymali odpowiednie wsparcie $\mathrm{w}$ postaci przygotowania do pracy $\mathrm{z}$ dzieckiem $\mathrm{z}$ lekką niepełnosprawnością intelektualną. Chodziło o ustalenie, jakie oczekiwania wsparcia $\mathrm{w}$ zakresie pracy $\mathrm{w}$ wyróżnionym obszarze mają nauczyciele oraz określenie ich aktualnego poziomu przygotowania do pracy $\mathrm{z}$ dzieckiem z lekką niepełnosprawnością intelektualną.

W badaniach uczestniczyło 120 nauczycieli szkół podstawowych ogólnodostępnych $\mathrm{z}$ województwa wielkopolskiego. Zostało przeprowadzone metodą sondażu diagnostycznego, z wykorzystaniem kwestionariusza ankiety. Grupę badanych nauczycieli w połowie stanowili nauczyciele uczący $\mathrm{w}$ nauczaniu początkowym, w drugiej połowie - nauczyciele przedmiotowi. W grupie nauczycieli nauczania początkowego nie było mężczyzn, natomiast $\mathrm{w}$ grupie nauczycieli przedmiotowych było ich 8 , co stanowiło $13 \%$ tej grupy. Z uwagi na tak małą reprezentację płci męskiej, jako zmiennej, nie brano jej pod uwagę w przeprowadzonej analizie wyników badań. Staż zawodowy badanej grupy nauczycieli przedstawia tabela 2 .

13 I. Chrzanowska, Problemy edukacji dzieci i młodzieży z niepetnosprawnościa, Kraków 2010, s. 29. 
Tabela 2

Staż zawodowy nauczycieli

\begin{tabular}{|l|c|c|c|}
\hline Staż zawodowy & $\begin{array}{c}\text { Nauczyciele } \\
\text { nauczania } \\
\text { początkowego }\end{array}$ & $\begin{array}{c}\text { Nauczyciele } \\
\text { przedmiotowi }\end{array}$ & Suma \\
\hline 1-2 lat & 2 & 3 & 5 \\
\hline 3-5 lat & 26 & 16 & 42 \\
\hline 6-10 lat & 8 & 4 & 12 \\
\hline 11-20 lat & 7 & 18 & 25 \\
\hline Powyżej 20 lat & 17 & 19 & 36 \\
\hline
\end{tabular}

Źródło: badania własne.

Wśród badanej grupy tylko czterech nauczycieli miało ukończone kursy z zakresu oligofrenopedagogiki. Natomiast, kontakt z uczniem z niepełnosprawnością intelektualną w pracy dydaktycznej zadeklarowało 69 nauczycieli, co stanowi 57,5\% badanej grupy (w tym aż 69,5\% (48 osób) stanowili nauczyciele nauczania początkowego). Wskazuje to na zależność, iż w nauczaniu początkowym w szkole ogólnodostępnej jest więcej uczniów z lekką niepełnosprawnością intelektualną, niż na drugim poziomie edukacji. Taka sytuacja może wynikać z faktu, iż część uczniów z lekką niepełnosprawnością intelektualną po zakończeniu pierwszego etapu edukacji, z uwagi na brak sukcesów, przenosi się do szkół specjalnych lub klas integracyjnych, lub dzieci te jeszcze nie dotarły do drugiego etapu edukacji, jako że rozporządzenie umożliwiające edukację osób z niepełnosprawnością intelektualną weszło w życie w roku 2011. Warto jednak podkreślić, że ponad połowa nauczycieli uczyła już dziecko z lekką niepełnosprawnością intelektualną, a pomimo tego poczucie przygotowania respondentów do pracy z uczniem z lekką niepełnosprawnością intelektualną jest bardzo niskie, na co wskazują dane zamieszczone $\mathrm{w}$ tabeli 3 .

Tabela 3

Poziom poczucia przygotowania nauczycieli do pracy z uczniem

z lekką niepełnosprawnością intelektualną

\begin{tabular}{|l|c|c|c|}
\hline $\begin{array}{c}\text { Poczucie przygotowania } \\
\text { do pracy z uczniem z lekką } \\
\text { niepełnosprawnością } \\
\text { intelektualną }\end{array}$ & $\begin{array}{c}\text { Nauczyciele } \\
\text { nauczania } \\
\text { początkowego }\end{array}$ & $\begin{array}{c}\text { Nauczyciele } \\
\text { przedmiotowi }\end{array}$ & Suma \\
\hline Bardzo dobre & 4 & 3 & 7 \\
\hline Średnie & 7 & 8 & 15 \\
\hline Niewielkie & 10 & 9 & 19 \\
\hline Brak przygotowania & 32 & 34 & 66 \\
\hline Nie mam zdania & 7 & 6 & 13 \\
\hline
\end{tabular}

Źródło: badania własne. 
Deklarowany niski poziom poczucia przygotowania nauczycieli do pracy z uczniem z lekką niepełnosprawnością intelektualną potwierdzają cytowane wcześniej badania. Warto jednak zwrócić uwagę, iż badania te w większości były przeprowadzone co najmniej 4-5 lat wcześniej, co implikuje stwierdzenie, iż przez ten czas, pomimo zmiany przepisów udostępniających dzieciom z lekką niepełnosprawnością intelektualną możliwość edukacji w szkolnictwie masowym, nauczyciele nie podnieśli swoich kompetencji $\mathrm{w}$ tym zakresie.

Potwierdzają to również wyniki badań odnoszących się do korzystania przez nauczycieli z literatury fachowej dotyczącej dzieci ze specjalnymi potrzebami edukacyjnymi; aż $40 \%$ badanych respondentów zadeklarowała, iż $\mathrm{w}$ ostatnich dwóch latach nie korzystała $\mathrm{z}$ literatury fachowej na ten temat, $38 \%$ stwierdziło, iż korzystało sporadycznie, a tylko $22 \%$ określa, że korzysta $\mathrm{z}$ tej wiedzy systematycznie ( $\mathrm{w}$ tym $65 \%$ stanowili nauczyciele nauczania początkowego, w przypadku wcześniejszych odpowiedzi różnice pomiędzy grupami nauczycieli były na poziomie 2-3\%). Warto jednak zwrócić uwagę, iż wśród nauczycieli, którzy zaznaczyli systematyczne korzystanie z wiedzy fachowej $45 \%$ respondentów nie potrafiło odpowiedzieć na pytania dotyczące nauczania dzieci z lekką niepełnosprawnością intelektualną.

Nauczyciele w niewielkim wymiarze uczestniczyli też w szkoleniach na temat pracy $\mathrm{z}$ dzieckiem ze specjalnymi potrzebami edukacyjnymi; $30 \%$ respondentów stwierdziło, iż $\mathrm{w}$ ostatnich czterech latach nie uczestniczyli w takich szkoleniach. Należy zauważyć, że w grupie tej przeważali nauczyciele przedmiotowi (30 osób - 83,3\%). W jednym lub dwóch spotkaniach $\mathrm{z}$ metodykiem na ten temat uczestniczyło $38 \%$ badanych (nie było znaczących różnic pomiędzy nauczycielami nauczania początkowego i przedmiotowego). Natomiast, udział $\mathrm{w}$ kursach (1-2) dotyczących pracy, diagnozy dzieci ze SPE zadeklarowało 8,3\% respondentów, w powyżej 4 kursach uczestniczyło $15 \%$ badanych nauczycieli i byli to w $90 \%$ nauczyciele nauczania początkowego. Wskazuje to, że nauczyciele nauczania początkowego częściej uczestniczą $\mathrm{w}$ kursach przygotowujących ich do pracy $\mathrm{z}$ dzieckiem ze specjalnymi potrzebami edukacyjnymi, jak też korzystają z literatury fachowej, co potwierdza dalsza analiza przeprowadzonych badań odnośnie posiadanej wiedzy na temat pracy z dzieckiem z lekką niepełnosprawnością intelektualną.

W ankiecie nauczyciele odpowiadali na kilka pytań dotyczących pracy z dzieckiem z lekką niepełnosprawnością intelektualną i na tej podstawie określono ich poziom wiedzy, który zaprezentowano w tabeli 4.

Prawie 56\% respondentów nie miało żadnej wiedzy na temat pracy z osobami z lekką niepełnosprawnością intelektualną, u 16\% zanotowano 
niski jej poziom, natomiast u 9\% badanych wysoki. Pomiędzy obydwoma grupami nauczycieli można zauważyć znaczne różnice potwierdzające wcześniejsze wyniki, z których można wysunąć konkluzję, że nauczyciele nauczania początkowego charakteryzują się wyższym poziomem wiedzy na temat pracy z uczniem z lekką niepełnosprawnością intelektualną.

Tabela 4

Poziom wiedzy nauczycieli na temat pracy z uczniem

z lekką niepełnosprawnością intelektualną

\begin{tabular}{|l|c|c|c|}
\hline $\begin{array}{c}\text { Poziom wiedzy na temat } \\
\text { pracy z uczniem z lekką } \\
\text { niepełnosprawnością } \\
\text { intelektualną }\end{array}$ & $\begin{array}{c}\text { Nauczyciele } \\
\text { nauczania } \\
\text { początkowego }\end{array}$ & $\begin{array}{c}\text { Nauczyciele } \\
\text { przedmiotowi }\end{array}$ & Suma \\
\hline Wysoki & 8 & 3 & 11 \\
\hline Średni & 19 & 4 & 23 \\
\hline Niski & 10 & 9 & 19 \\
\hline Brak wiedzy & 23 & 44 & 67 \\
\hline
\end{tabular}

Źródło: badania własne.

Warto zwrócić uwagę, że źródło wiedzy z jakiej czerpią informacje o dzieciach z lekką niepełnosprawnością intelektualną nauczyciele, to najczęściej środki masowego przekazu, życie prywatne i zajęcia na studiach. Rzadziej korzystają z różnych form dokształcania ustawicznego, takich jak kursy czy studia podyplomowe, co potwierdza ich deklaracje niewielkiego uczestnictwa $w$ takich formach dokształcania. Szczegółowy rozkład wyników przedstawia rycina 1.

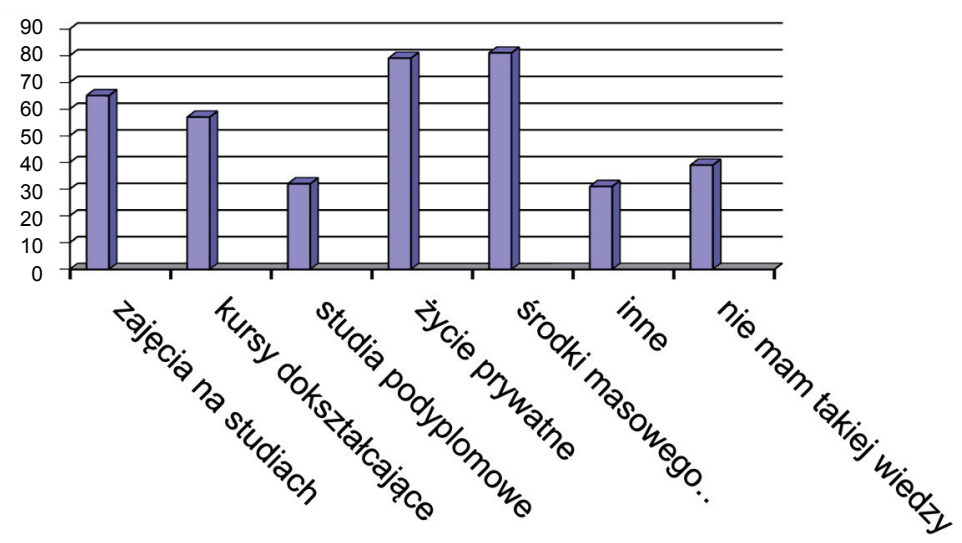

Ryc. 1. Źródło wiedzy na temat dzieci z lekką niepełnosprawnością intelektualną wskazywane przez nauczycieli (źródło: badania własne) 
W badaniu tym nauczyciele mogli zaznaczyć więcej niż jedną odpowiedź, stąd liczba wybranych odpowiedzi przekracza liczbę uczestników badań. W przypadku zaznaczenia przez respondenta innego źródła wiedzy, tylko 12 osób zadeklarowało jakie ono jest: 8 osób wskazało na spotkania $\mathrm{z}$ metodykiem w szkole, a trzech respondentów wymieniło Internet.

Po określeniu ogólnego poziomu przygotowania i wiedzy nauczycieli na temat pracy z uczniami z lekką niepełnosprawnością intelektualną, można przejść do głównego problemu przeprowadzonych badań, czyli określenia, jakie są oczekiwania i potrzeby nauczycieli szkół ogólnodostępnych związane $\mathrm{z}$ podjęciem pracy lub pracą z uczniem $\mathrm{z}$ niepełnosprawnością.

Analiza wyników przeprowadzonych badań wskazuje, że nauczyciele oczekują pomocy $\mathrm{w}$ przygotowaniu do pracy z dzieckiem $\mathrm{z}$ niepełnosprawnością intelektualną głównie od psychologa, pedagoga szkolnego, później od zespołu samoszkoleniowego i dyrekcji szkoły. Rozkład tych oczekiwań prezentuje rycina 2 .

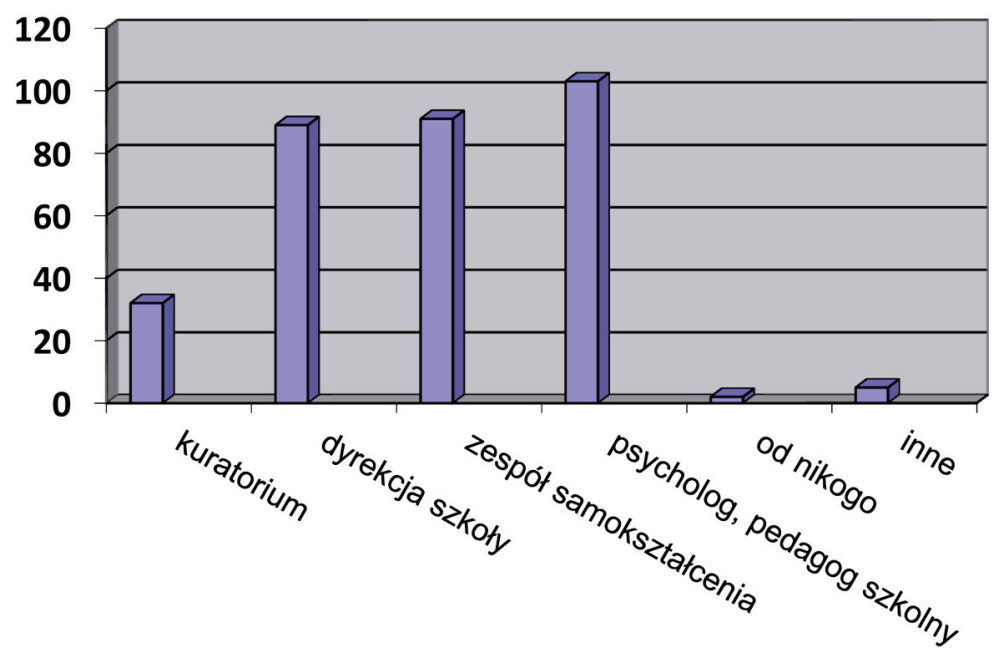

Ryc. 2. Osoby, instytucje od których oczekują wsparcia nauczyciele w przygotowaniu do pracy z dzieckiem z niepełnosprawnością intelektualną (źródło: badania własne)

Warto zauważyć, że tylko dwie osoby zadeklarowały, że nie potrzebują wsparcia w tej dziedzinie, pięć zaznaczyło odpowiedź „inne”, dwie nie wpisały od kogo takiego wsparcia oczekują, natomiast pozostałe trzy wskazały na samych siebie. Wyniki tych badań obrazują jednak, że większość nauczycieli oczekuje wsparcia ze strony swojego miejsca pracy, to jest pedagoga, psychologa szkolnego, czy zespołu samokształceniowego. $\mathrm{W}$ badaniu tym 
nauczyciele mogli zaznaczyć więcej niż jedną odpowiedź, stąd liczba wybranych odpowiedzi przekracza liczbę uczestników badań. Na pytanie nie odpowiedziało czterech respondentów. Nie zanotowano w nim też znaczących różnic pomiędzy nauczycielami nauczania początkowego a przedmiotowego.

Na podstawie wyników badań można określić, iż nauczyciele oczekują wsparcia od osób z zewnątrz, ale jak się okazuje, nie bardzo potrafią określić, jakich obszarów miałoby ono dotyczyć, co obrazuje tabela 5.

Tabela 5

Obszary w jakich nauczyciele oczekują wsparcia w celu efektywnej pracy z dzieckiem $\mathrm{z}$ niepełnosprawnością intelektualną

\begin{tabular}{|l|c|c|c|}
\hline \multicolumn{1}{|c|}{ Obszary wsparcia } & $\begin{array}{c}\text { Nauczyciele } \\
\text { nauczania } \\
\text { początkowego }\end{array}$ & $\begin{array}{c}\text { Nauczyciele } \\
\text { przedmiotowi }\end{array}$ & Suma \\
\hline $\begin{array}{l}\text { Konsultacje } \\
\text { ze specjalistami }\end{array}$ & 26 & 11 & 37 \\
\hline Zapewnienie praktyki & 8 & 16 & 51 \\
\hline $\begin{array}{l}\text { Przygotowanie mery- } \\
\text { toryczne - kursy }\end{array}$ & 35 & 29 & 61 \\
\hline $\begin{array}{l}\text { Zmiana liczebności } \\
\text { dzieci w klasie }\end{array}$ & 32 & 12 & 38 \\
\hline $\begin{array}{l}\text { Wprowadzenie } \\
\text { nauczyciela } \\
\text { wspomagającego }\end{array}$ & 26 & 15 & 29 \\
\hline $\begin{array}{l}\text { Odpowiednie wypo- } \\
\text { sażenie sal, szkoły }\end{array}$ & 14 & 11 & 28 \\
\hline $\begin{array}{l}\text { Odpowiednie pomoce } \\
\text { dydaktyczne }\end{array}$ & 17 & 2 & 64 \\
\hline We wszystkim & 5 & 41 & 7 \\
\hline Brak odpowiedzi & 23 & & \\
\hline
\end{tabular}

Źródło: badania własne.

W pytaniu tym nie wyróżniono poszczególnych kategorii, aby nie sugerować odpowiedzi nauczycielom, zatem respondenci mogli podać więcej niż jedną odpowiedź, stąd liczba wybranych odpowiedzi przekracza liczbę uczestników badań. Przedstawione w tabeli obszary są wynikiem skategoryzowania udzielonych przez nauczycieli odpowiedzi. Niepokojący wydaje się fakt, iż połowa respondentów nie udzieliła odpowiedzi na to pytanie, przez co nie określa w żaden sposób swoich oczekiwań. Można się zastanawiać, z czego to wynika: czy z tak niskiego poziomu wiedzy, że nie potrafią nauczyciele określić własnych potrzeb, braków w badanym obszarze, czy braku chęci do podejmowania podnoszenia kompetencji w zakresie tego 
zagadnienia, czy może braku zauważenia takiej potrzeby. Niski poziom wiedzy, potwierdzony przez wcześniejszą analizę wyników przeprowadzonych badań, ma swoje odzwierciedlenie $\mathrm{w}$ wyróżnionych przez nauczycieli obszarach, które były bardzo mało sprecyzowane. Tylko u pięciu respondentów wyróżnione przez nich obszary określały szczegółowe oczekiwania co do zakresu wiedzy, czy rodzaju kursu, jaki jest im potrzebny do podniesienia kompetencji do pracy z dzieckiem z niepełnosprawnością intelektualną. Najwięcej nauczycieli, bo aż $50 \%$, oczekuje wsparcia w postaci zmiany liczebności dzieci w klasie. Nauczyciele nie widzą możliwości pracy z dzieckiem z niepełnosprawnością intelektualną $\mathrm{w}$ tak licznych klasach. Na ten problem nauczyciele zwracali już uwagę, odpowiadając na pytanie służące określeniu ich poziomu wiedzy, podając indywidualizację jako jeden ze znaczących problemów w pracy z tymi dziećmi. Potwierdza to również analiza wyników dotyczących ustosunkowania się do pytania, czy według nich można zapewnić indywidualne podejście do dziecka z niepełnosprawnością intelektualną w przeciętnej klasie liczącej 22-26 osób. Respondenci na to pytanie w 73\% odpowiedzieli przecząco, w 15\% uznali, że jest możliwe sporadycznie, w 10\% zadeklarowali, że indywidualizacja jest możliwa, ale tylko w wybranych aktywnościach i zaledwie $2 \%$ badanych nauczycieli odpowiedziała twierdząco.

Następny, najliczniej prezentowany, oczekiwany przez nauczycieli, obszar wsparcia stanowi przygotowanie merytoryczne. W ramach tego obszaru nauczyciele pisali najczęściej bardzo ogólnie; „wiedza”, " kursy”, "merytoryczne wsparcie". Jak wspomniano wcześniej, tylko w przypadku pięciu osób obszar ten był dookreślony. Następnie nauczyciele oczekują konsultacji ze specjalistami, a także wprowadzenia nauczyciela wspomagającego. $\mathrm{W}$ wypowiedziach respondentów dotyczących wprowadzenia nauczyciela wspomagającego przeważały opinie, że to on powinien się specjalistycznie zająć uczniami z niepełnosprawnością intelektualną. Dalsze oczekiwania nauczycieli dotyczyły głównie wyposażenia klasy, szkoły - np. w miejsce do odpoczynku, zapewnienie większej przestrzeni, czy zapewnienie dostępu do odpowiednich dla dziecka z niepełnosprawnością intelektualną pomocy dydaktycznych.

W ramach wyróżnionych obszarów można zaobserwować znaczące różnice pomiędzy nauczycielami nauczania początkowego a nauczycielami uczącymi określonych przedmiotów. Nauczyciele przedmiotowi mają znacznie mniejsze oczekiwania odnośnie wsparcia merytorycznego i to zarówno odnoszącego się do kursów czy innych form szkolenia, konsultacji ze specjalistami, praktyki. Częściej wykazywali brak oczekiwań dotyczących wsparcia $\mathrm{w}$ pracy $\mathrm{z}$ dzieckiem $\mathrm{z}$ niepełnosprawnością intelektualną. Nato- 
miast, na podobnym poziomie z nauczycielami nauczania początkowego zadeklarowali potrzebę zmiany liczebności dzieci w klasie oraz jej wyposażenia.

Konkludując, nauczyciele przedmiotowi w znacznie mniejszym stopniu deklarują oczekiwania odnośnie wspierania podnoszenia ich kompetencji do pracy z dziećmi z lekką niepełnosprawnością intelektualną niż nauczyciele nauczania początkowego. W największym stopniu nauczyciele oczekują tego wsparcia $\mathrm{w}$ zakresie organizacji ich pracy, jak np. zmniejszenie liczebności dzieci w klasie, wyposażenie klasy czy szkoły, a w dość niewielkim stopniu w zakresie podnoszenia ich merytorycznych kompetencji.

Badani nauczyciele na pytanie: czego im brakuje do efektywnej pracy z dzieckiem ze specjalnymi potrzebami edukacyjnymi, w tym z lekką niepełnosprawnością intelektualną, odpowiedzieli w sposób bardzo podobny jak w przypadku oczekiwanych obszarów wsparcia do pracy z tymi dziećmi, co przedstawia tabela 6 .

Tabela 6

Braki postrzegane przez nauczycieli w celu efektywnej pracy z dzieckiem ze SPE w tym z niepełnosprawnością intelektualną

\begin{tabular}{|c|c|c|c|}
\hline Obserwowane braki & $\begin{array}{c}\text { Nauczyciele } \\
\text { nauczania } \\
\text { początkowego }\end{array}$ & $\begin{array}{l}\text { Nauczyciele } \\
\text { przedmiotowi }\end{array}$ & Suma \\
\hline $\begin{array}{l}\text { Przygotowania ogól- } \\
\text { nego do pracy } \\
\text { z dziećmi ze SPE }\end{array}$ & 24 & 13 & 37 \\
\hline Brak praktyki & 6 & 0 & 6 \\
\hline $\begin{array}{l}\text { Przygotowania } \\
\text { merytorycznego }\end{array}$ & 24 & 8 & 32 \\
\hline $\begin{array}{l}\text { Liczebność dzieci } \\
\text { w klasie }\end{array}$ & 21 & 18 & 39 \\
\hline $\begin{array}{l}\text { Brak nauczyciela } \\
\text { wspomagającego }\end{array}$ & 24 & 11 & 35 \\
\hline $\begin{array}{l}\text { Odpowiedniego } \\
\text { wyposażenia sal, } \\
\text { szkoły }\end{array}$ & 11 & 10 & 21 \\
\hline $\begin{array}{l}\text { Odpowiednich po- } \\
\text { mocy dydaktycznych }\end{array}$ & 11 & 10 & 21 \\
\hline $\begin{array}{l}\text { Czasu na lekcji - } \\
\text { przeciążenie materia- } \\
\text { łem }\end{array}$ & 17 & 21 & 38 \\
\hline $\begin{array}{l}\text { Godzin na zajęcia } \\
\text { pozalekcyjne, } \\
\text { np. wyrównawcze }\end{array}$ & 5 & 2 & 7 \\
\hline Brak odpowiedzi & 28 & 43 & 71 \\
\hline
\end{tabular}

Źródło: badania własne. 
W pytaniu tym, podobnie jak w poprzednim, nie wyróżniono poszczególnych kategorii, aby nie sugerować odpowiedzi nauczycielom, zatem respondenci mogli podać więcej niż jedną odpowiedź, stąd liczba wybranych odpowiedzi przekracza liczbę uczestników badań. Na podstawie odpowiedzi nauczycieli skategoryzowano bardzo podobne obszary zauważanych przez nich braków, jak też oczekiwań. Nowymi wyróżnionymi obszarami są: brak czasu na lekcji wynikający głównie z przeciążenia zakresu realizowanego programu oraz brak godzin na zajęcia pozalekcyjne, głównie dydaktyczno-wyrównawcze. Uwagę na brak czasu na lekcji w większości zwracali nauczyciele uczący przedmiotów, co może wiązać się z faktem, że pracują $\mathrm{w}$ systemie lekcyjnym 45 -minutowym, a nie jak $\mathrm{w}$ nauczaniu elementarnym systemem zajęć zintegrowanych. Natomiast, na brak godzin przeznaczonych na zajęcia dydaktyczno-wyrównawcze zwrócili uwage głównie nauczyciele nauczania początkowego, argumentując, iż po zabraniu im tych godzin, nie mają możliwości pracować indywidualnie z dzieckiem. Warto też zwrócić uwagę, iż więcej, niż w poprzednio analizowanym pytaniu, nauczycieli nie udzieliło odpowiedzi, co może zastanawiać, czy nie widzą braków uniemożliwiających lub przynajmniej obniżających im możliwość efektywnej pracy z dzieckiem z lekką niepełnosprawnością intelektualną? Mniej nauczycieli zauważa również braki w zakresie własnego przygotowania do pracy z dzieckiem z lekką niepełnosprawnością intelektualną, co $\mathrm{w}$ porównaniu $\mathrm{z}$ analizą wyników dotyczących poziomu ich wiedzy, czy chociażby deklarowanego poziomu przygotowania do pracy $\mathrm{w}$ tym obszarze, implikuje stwierdzenie, że nauczyciele prezentują niską refleksję odnośnie ich kompetencji zawodowych.

Analizując powyższe wyniki badań, można zadać pytanie: dlaczego przy tak niskim poziomie wiedzy i umiejętności do pracy z dzieckiem z lekką niepełnosprawnością intelektualną, szczególnie przy obecnej zmianie przepisów umożliwiających tym dzieciom edukację w szkole ogólnodostępnej, nauczyciele $\mathrm{w}$ tak niewielkim stopniu wykazują oczekiwania $\mathrm{w}$ zakresie podnoszenia kompetencji w tym obszarze? Żeby w pełni móc odpowiedzieć na te pytanie, należałoby przeprowadzić nowe badania na temat motywacji nauczycieli do podnoszenia swoich kwalifikacji. Na niski poziom korzystania z form kształcenia, nie tylko dotyczącego dzieci ze SPE, zwraca uwage NIK w swoim raporcie dotyczącym kształcenia i doskonalenia zawodowego nauczycieli. W roku szkolnym 2010/2011 nie uczestniczyło w żadnej z zewnętrznych form kształcenia i doskonalenia zawodowego 462 nauczycieli (33\% względem ogółu 1383 nauczycieli zatrudnionych w skontrolowanych jednostkach). W raporcie zwrócono uwagę, iż najrzadziej $\mathrm{w}$ szkoleniach uczestniczą nauczyciele dyplomowani; spośród 774 nauczycieli dyplomo- 
wanych łącznie 269 osób (35\%) nie uczestniczyło w trakcie kolejnych trzech lat szkolnych w zewnętrznych formach kształcenia i doskonalenia zawodowego. Według raportu NIK, nieprawidłowości dotyczyły również szkolenia wewnątrzszkolnego; w pięciu szkołach (22\%) ograniczono się do przeprowadzenia od jednego do trzech posiedzeń szkoleniowych rad pedagogicznych, a w siedmiu szkołach (30\%) z możliwości doskonalenia zawodowego korzystali tylko pojedynczy nauczyciele. Raport wskazuje również, że nauczyciele kończą różne formy kształcenia i następnie nie wykorzystują zdobytych kwalifikacji, co świadczy o braku rozpoznania przez dyrektorów szkół potrzeb kształcenia i doskonalenia zawodowego nauczycieli. Z kontroli NIK wynika, że dyrektorzy szkół nie zapewniali nauczycielom wystarczającej pomocy $w$ doskonaleniu zawodowym oraz nie wykorzystywali instrumentów nadzoru pedagogicznego i oceny pracy ${ }^{14}$. Zgodnie $\mathrm{z}$ raportem NIK można stwierdzić, że nauczyciele nie wykorzystują szansy na podniesienie swoich kwalifikacji, co jest szczególnie ważne w sytuacji wdrażania nowych zmian w systemie oświaty, między innymi dotyczących uczestnictwa dzieci z lekką niepełnosprawnością intelektualną w szkolnictwie ogólnodostępnym. Warto jednak zauważyć, że brak podnoszenia przez nauczycieli kwalifikacji zawodowych powoduje niewypełnienie obowiązku, do którego obliguje ich Karta Nauczyciela.

Jednakże, w przypadku podnoszenia kwalifikacji zawodowych w zakresie pracy z dzieckiem z lekką niepełnosprawnością intelektualną, może mieć znaczenie fakt, iż nauczyciele nie popierają edukacji tych dzieci w szkołach ogólnodostępnych, co przedstawia rycina 3.

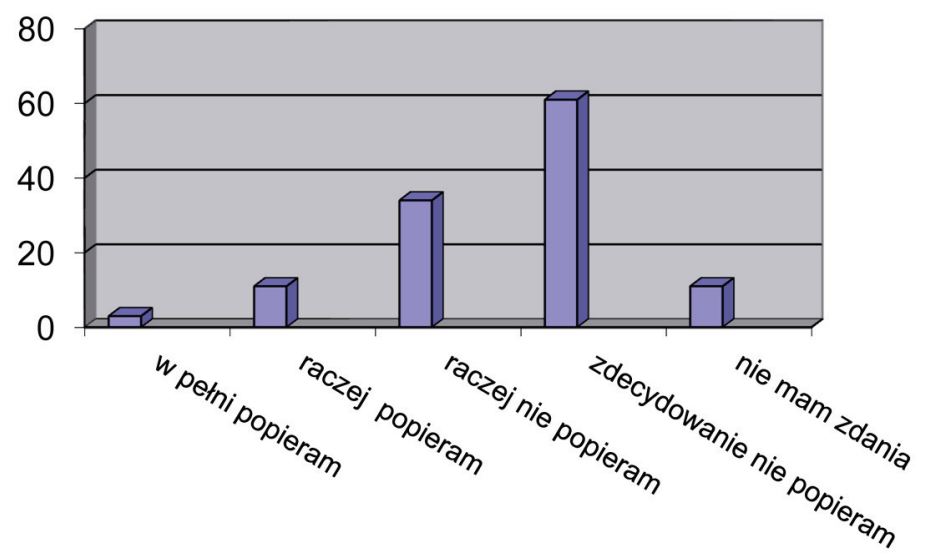

Ryc. 3. Opinie nauczycieli na temat kształcenia osób z lekką niepełnosprawnością intelektualną w szkole ogólnodostępnej (źródło: badania własne)

14 nik.gov.pl. 
Analizując wyniki badań, okazuje się, że 51\% badanej grupy zdecydowanie nie popiera edukacji dzieci z lekką niepełnosprawnością intelektualną w szkole ogólnodostępnej, $28 \%$ respondentów raczej nie popiera, a tylko 2,5\% w pełni popiera taki model ich edukacji. Wyniki tych badań są zgodne z wynikami badań przeprowadzonymi przez Z. Gajdzicę ${ }^{15}$, który prowadząc badania nauczycieli $(\mathrm{N}=183)$ w 2009 r., uzyskał następujące wyniki: w 48\% respondenci zadeklarowali zupełny brak poparcia $\mathrm{w}$ zakresie kształcenia osób z lekką niepełnosprawnością intelektualną w szkole ogólnodostępnej, w 35\% - umiarkowany brak poparcia, natomiast pełne poparcie dla takiej edukacji zadeklarowało 2,7\% nauczycieli. Podobne wyniki, wcześniej przedstawione, uzyskała K. Błeszyńska.

Biorąc pod uwagę,

że nauczyciel nigdy nie pracuje dla siebie, dla własnej satysfakcji, bierze on pod opiekę drugiego człowieka, a zarazem jego przyszłość, gdyż przygotowuje go do pełnego i odpowiedzialnego uczestnictwa w społeczeństwie16,

warto się zastanowić, jak zapewnić nauczycielom odpowiednie przygotowanie do pracy z dzieckiem ze specjalnymi potrzebami edukacyjnymi. Jak ich zmotywować do podnoszenia kompetencji zawodowych w tym zakresie, by mogli przygotować do pełnego i odpowiedzialnego uczestnictwa w społeczeństwie również dziecko z lekką niepełnosprawnością intelektualną.

\section{BIBLIOGRAFIA}

Al-Khamisy D., Gotowość nauczycieli edukacji przedszkolnej do pracy z dziećmi o specjalnych potrzebach edukacyjnych, [w:] Integracja społeczna osób niepetnosprawnych, red. G. Dryżałowska, H. Żuraw, Wydawnictwo Akademickie Żak, Warszawa 2004.

Bartnikowska U., Wójcik M., Zaniedbania w aspekcie triady: szkota-rodzice-dziecko w kształceniu integracyjnym i masowym dzieci z wada stuchu, [w:] Watki zaniedbane, zaniechane, nieobecne w procesie edukacji i wsparcia społecznego osób niepetnosprawnych, red. Z. Gajdzica, D. Osik-Chudowolska, Wydawnictwo UMCS, Lublin 2004.

Chodkowska M., Problemy pedagogicznego wsparcia uczniów z niepetnosprawnościa intelektualna w zakresie społecznego funkcjonowania w klasie szkolnej, [w:] Wsparcie społeczne w rehabilitacji $i$ resocjalizacji, red. Z. Palak, Z. Bartkowicz, Wydawnictwo UMCS, Lublin 2004.

Chrzanowska I., Problemy edukacji dzieci i młodzieży z niepetnosprawnościa, Oficyna Wydawnicza Impuls, Kraków 2010.

${ }^{15}$ Z. Gajdzica, Opinie nauczycieli szkót ogólnodostępnych, s. 76-77.

16 J. Moritz, Refleksje na temat kształcenia nauczycieli, Nowa Szkoła, 2008, 1, s. 33. 
Ćwirynkało K., Pozycja socjometryczna uczniów niepetnosprawnych a postawa nauczycieli wobec integracji, [w:] Integracja osób niepetnosprawnych w edukacji i interakcjach społecznych, red. Z. Kazanowski, D. Osik-Chudowolska, Wydawnictwo UMCS, Lublin 2003.

Gajdzica Z., Nauczyciel edukacji wczesnoszkolnej w zreformowanej szkole powszechnej jako organizator procesu kształcenia dziecka upośledzonego umysłowo w stopniu lekkim, [w:] Pedagogika specjalna w reformowanym ustroju edukacyjnym, red. Z. Palak, Wydawnictwo UMCS, Lublin 2001.

Gajdzica Z., Opinie nauczycieli szkót ogólnodostępnych na temat edukacji włączającej uczniów z lekkim upośledzeniem umystowym w kontekście toczacej się reformy kształcenia specjalnego, [w:] Uczeń z niepetnosprawnościa w szkole ogólnodostępnej, red. Z. Gajdzica, Oficyna Wydawnicza Humanista, Sosnowiec 2011.

Garlej-Drzewiecka E., Pedeutologiczny kontekst myślenia o nauczycielu wiodącym i wspierającym, [w:] Dyskursy pedagogiki specjalnej. Wspótczesne problemy pedagogiki specjalnej, red. Cz. Kosakowski, A. Krause, Wydawnictwo UWM, Olsztyn 2004.

Informacja o wynikach kontroli NIK, Organizacja i finansowanie ksztatcenia $i$ doskonalenia zawodowego nauczycieli, 2012: www.nik.gov.pl [data dostępu: 11.03.2013].

Jachimczak B., Gotowość nauczycieli szkót ogólnodostępnych do pracy z uczniem o specjalnych potrzebach edukacyjnych, [w:] Miejsce Innego we wspótczesnych naukach o wychowaniu wyzwania praktyki, red. I. Chrzanowska, B. Jachimczak, Wydawnictwo Satori, Łódź 2008.

Jankowska D., Uczeń z niepetnosprawnościa intelektualna w stopniu lekkim w szkole ogólnodostępnej - problem czy wyzwanie, [w:] Uczeń z niepetnosprawnością w szkole ogólnodostępnej, red. Z. Gajdzica, Oficyna Wydawnicza Humanista, Sosnowiec 2011.

Kosakowski Cz., Dziecko niepetnosprawne w kształceniu integracyjnym, [w:] Nauczanie i wychowanie osób lekko upośledzonych umystowo, red. Cz. Kosakowski, Wydawnictwo Akapit, Torun 2000.

Kosakowski Cz., Dziecko niepetnosprawne w szkole masowej - możliwości i ograniczenia, [w:] Dziecko o specjalnych potrzebach edukacyjnych, red. Cz. Kosakowski, M. Zaorska, Wydawnictwo Akapit, Torun 2001.

Moritz J., Refleksje na temat ksztatcenia nauczycieli, Nowa Szkoła, 2008, 1.

Osik-Chudowolska D., Ustosunkowania emocjonalne uczniów petnosprawnych do niepetnosprawnych rówieśników w szkole z oddziałami integracyjnymi, [w:] Dyskursy pedagogiki specjalnej. Rehabilitacja, opieka i edukacja specjalna w perspektywie zmian, red. U. Bartnikowska, Cz. Kosakowski, A. Krause, Wydawnictwo UWM, Olsztyn 2008.

Parys K., Problemy integracji szkolnej w badaniach empirycznych - przegląd materiałów pokonferencyjnych, [w:] Problemy edukacji integracyjnej dzieci i młodzieży z niepetnosprawnościa intelektualna, red. Z. Janiszewska-Nieścioruk, Oficyna Wydawnicza Impuls, Kraków 2009.

Wachowiak A., Błędy nauczycieli szkół masowych w postępowaniu z dziećmi niepetnosprawnymi, [w:] Uczeń niepetnoprawny w szkole masowej, red. A. Hulek, B. Grochmal-Bach, Wydawnictwo WSP, Kraków 1992.

Zamkowska A., Wsparcie edukacyjne uczniów z upośledzeniem umystowym w stopniu lekkim w różnych formach ksztatcenia na I etapie edukacji, Wydawnictwo Politechniki Radomskiej, Radom 2009. 